\title{
Managment of the Small and Medium Enterprises
}

Drita Krasniqi PhDc

\author{
Lecturer Universitety of Prizren "Ukshin Hoti"
} dritakrasniqi@yahoo.com

Doi:10.5901/ajis.2014.v3n3p439

\begin{abstract}
Small and medium enterprises have a special importance for the economy of a country. The role and importance of small and medium enterprises (SME) can be seen from the economic and social aspect, because of their contribution to operation of economic system and the creation of new jobs. Therefore it is considered that these enterprises are the main generators of employment. The basic purpose of this paper is the diagnosis of the current situation of the micro small and medium enterprises. Another goal of this research is to lay out significant results for existing condition, structure, problems, difficulties, and to measure the trend of development of these enterprises. Classification of (SME) according to the number of employee, and classification according to the legal status. Another importance shows the structure of managing these (SME) by fiscal number. Special emphasis has also the structure of these enterprises according to the gender of employees, expressed as a percentage thus making a comparison of the participation of women in the labor market compared to men.
\end{abstract}

Keywords: Economic, management, businesses, structure of SME

\section{Different Approaches to the Definition of Small Business and the Middle Business}

In today's literature, but also in everyday life is a broad term associated with enterprise, namely small and medium enterprises (SMEs / SMBs). However there is no consensus on what are the criteria that define an enterprise or business to be small or medium.

SME development in Kosovo offers new employment opportunities, which help reduce unemployment and demographic challenges facing the population, which are growing rapidly. In addition, the development of the SME sector contributes to strengthening the competitiveness and productivity, helping to increase the total income and per capita income in the country. This development promotes structural transformation of the SME sector, due to its link with innovation and technological development in general. The process contributes to regional and local development and social cohesion, enabling the reduction of inequality

One of the definitions for small businesses is provided by the "Committee for econimic Development", under which must be met two or more of the following characteristics:

$>$ Management of the firm is independent and usually managers are also owners

$>$ Capital is owned by an individual or a small group;

$>$ Region mainly interment is small, and the employees and owners are from the same region. But the market does not mean to be local.

Relative size of firm in the industry frames must be small when compared with larger enterprises in the region.

This can be presented in terms of sales as size, the number of employees or a large number of key comparisons.

It is clear that in the definition of small and medium must be taken into account more criteria, which can help (Mustafa M, Kutllovci E, Gashi P, Krasniqi B, 2006).

\section{Specifics of Small and Medium}

There are fundamental differences between small and large, which should be taken into account when discussing the implementation of management. Thus, for eg. small and have few employees, working small size, small number of Customer and operating primarily in local markets. To clarify the differences in the application of management in small and large, it is necessary to clarify some additional features to small enterprises which are different from large enterprises, they are:

$>$ Making decisions faster

$>$ greater flexibility

$>$ greater centralization in decision-making, organizational structure simple

$>$ owner's big impact, direct communication from the top down, simple formal planning 
Participation limited employed in decision making, fewer management layers (Mustafa M, Kutllovci E, Gashi P,Krasniqi B, 2006).

\section{Registered Businesses in Kosovo}

Enterprise fundamental institution of social reproduction-is the subject of much research in economic sciences. That took more theory or theories taken menjohurit economic enterprise. In this case we are dealing with a specific view of enterprise-word is for the knowledge of some specifications, features, attributes, or characteristics of the enterprise (Myftari, 2010).

SME has a very important impact on employment growth in certain countries. It is considered that about $60-70 \%$ of the new places of work in countries more developed parts of the world, achieved as a result of the recruitment of adjacent SMEs (Stienholf, 1998).

Selection and the difference of small and medium enterprises from large ones, according to criteria set by the European Union done in this way:

$>$ micro-enterprises employing 1-9 workers;

> small - employing 10 to 49 workers;

$>$ sized enterprises - 50 to 249 workers. (mti-ks.org, 2005).

On 17 October 2008, the Kosovo Assembly adopted the Law 03/L-031 which replaced the Law on SME support $.02 / L-5$ and which govern the determination of the size of enterprises in Kosovo (mei-ks.org, 2012).

Table nr.1: Enterprises classification according to EU and KS

\begin{tabular}{|l|c|c|}
\hline \multicolumn{1}{|c|}{ Classification of enterprises by size } & $\begin{array}{c}\text { EU } \\
\text { procedure }\end{array}$ & $\begin{array}{c}\text { KS } \\
\text { procedure }\end{array}$ \\
\hline Middle & under 250 & under 250 \\
\hline Small & under 50 & under 50 \\
\hline Micro & under 10 & under 10 \\
\hline
\end{tabular}

Source: ARBK(Agjencia për regjistrimin e bizneseve në Kosovë)

In Kosovo SMEs constitute the dominant number of registered enterprises. Under the ARBK, the number of SMEs registered on December 31, 2010 was greater than 100,000, which employ 216,799 workers, or $79.59 \%$ of the total employees in the private sector and $62.24 \%$ of the total employees in Kosovo (mti-ks.org, Strategjia e zhvillimit të NVMve në Kosovë, 2011).

Size of SMEs in Kosovo is determined by Law no . 2005/02-L5 and the Law no. 03/L-031 to support Small and Medium Enterprises. The number of employees is the only criterion in Kosovo (mti-ks.org, Strategjjia për zhvillimin e NVM-ve 2012-2016, 2011). for classification of size of the enterprises. This represents the difference with the EU countries, where beside the number of employees, annual turnover is taken into consideration. .

Important considering the structure of employment in Kosovo, particularly employment categories enterprises (micro, small and medium enterprises), we extracted the results from the processing of data which are presented in table

Table nr.2: Employment by enterprise categories

\begin{tabular}{|c|c|c|}
\hline $\begin{array}{c}\text { Categories according to the number of } \\
\text { employees' }\end{array}$ & $\begin{array}{c}\text { Number of businesses } \\
(\mathbf{3 1 . 1 2 . 2 0 1 0 )}\end{array}$ & $\begin{array}{c}\text { Number of employees } \\
\mathbf{( 3 1 . 1 2 . 2 0 1 0 )}\end{array}$ \\
\hline $1-9$ & 102070 & 171393 \\
\hline $10-49$ & 1406 & 23380 \\
\hline $50-249$ & 221 & 22026 \\
\hline $250----$ & 58 & 55658 \\
\hline Total & 103755 & 272457 \\
\hline
\end{tabular}

Source: ARBK

Out of a total of 103,755 enterprises: 102,070 (or 98.37\%) are micro-enterprises; 1406 (1:35\%) are small; 221 (0.22\%) are secondary and only 58 (12:06\%) classified as major. 
Tabela nr.3: Registered Enterprises in Kosovo by Number of Employees - 2010

\begin{tabular}{|l|c|c|c|}
\hline Classfication by Size & Number of employees & Number of enterprises & Percentage of total \\
\hline Micro & $1-9$ & 102,070 & 98.37 \\
\hline Small & $10-49$ & 1,406 & 1.35 \\
\hline Middle & $50-249$ & 221 & 0.22 \\
\hline Large Total & 250 e më shumë & 58 & 0.06 \\
\hline \multicolumn{1}{|r|}{} & 103,755 & 100.00 \\
\hline
\end{tabular}

\section{Source: ARBK}

Enterprises registered in Kosovo under the ownership structure are as follows:

Type of ownership The number of enterprises in \%

- Individual Business 90,00

- General partnership 3,20

- Limited partnership 0,08

- Limited liability company 5,80

- Joint Stock Company 0,35

- Foreign-owned Enterprise 0,46

- Social Enterprise 0,01

- Public Enterprises 0,01

- Agricultural Cooperative 0,06

- Others 0.03

Total $100 \%$

Details ARBK presented inabove provide information about the ownership structure of companies registered in Kosovo. Individual businesses clearly dominate with $90 \%$ ownership structure. The rest of the companies are general partnerships (3.2\%) and limited liability companies (5.8\%). (mti-ks.org, Strategjian e zhvillimit të NVM-venë Kosovë, 2011).

Certainly the type of ownership of the above shows disadvantages of SMEs in Kosovo, because it shows the reluctance of SME owners to joining the financial and human capital in the most advanced forms of business (mti-ks.org, Strategjian e zhvillimit të NVM-venë Kosovë, 2011).

\section{General Data on the Structure of SMEs in Kosovo}

\subsection{Enterprises by management}

Apparently legal statutes size enterprises and tours, has an impact on the form of management. Results from the survey show that to MSMEs in Kosovo still does not have separation of ownership and management functions. In fact, by all enterprises surveyed can see that $86.46 \%$ of them are managed by the owners and only $13.54 \%$ are managed by appointed managers.

Table nr.4: MSMEs by leaders manager

\begin{tabular}{|c|c|c|c|c|c|c|c|c|c|c|c|c|}
\hline 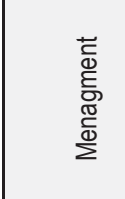 & 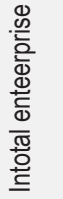 & $\therefore$ & 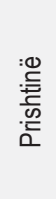 & $0^{\circ}$ & 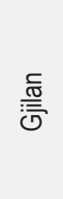 & $0^{\circ}$ & $\frac{\omega}{\alpha}$ & $\alpha^{\circ}$ & 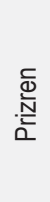 & ๙̊ & 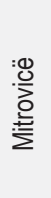 & ๙̊ \\
\hline \begin{tabular}{|l} 
Owner \\
\end{tabular} & 667 & 86.46 & 226 & 88.28 & 151 & 86.29 & 121 & 87.68 & 109 & 78.99 & 70 & 92.11 \\
\hline Menager & 106 & 13.54 & 30 & 11.72 & 24 & 13.21 & 17 & 12.32 & 29 & 21.01 & 6 & 7.89 \\
\hline Total & 783 & 100 & 256 & 100 & 175 & 100 & 138 & 100 & 138 & 100 & 76 & 100 \\
\hline
\end{tabular}

Source: Report - Survey 800 of SMSs 
From this we see that the greater the number of enterprises that are managed by the owners in the Mitrovica region is $92.11 \%$, while the number of smaller enterprises that are managed by the owners in Prizren region is $78.99 \%$.

While greater the number of enterprises that are managed by managers in the Prizren region is $21.1 \%$ lower while the number of enterprises that are managed by the owners of the Mitrovica region is $7.89 \%$. (mti-ks.org-Agjencia për mbështetjen e NVM-ve, 2011).

\subsection{Structure of the founders of the founders of SMEs}

Structure of the founding owners of enterprises is an important element in the analysis and monitoring of activities of enterprises. although in our country, women's participation in leadership and small enterprises has in recent years seen an increase of women's participation in the registration of enterprises.

The table data are carried on the participation and role of women in the ownership of enterprises by such over by no positive effect on economic development. In this table are they presented data from the ownership of women at the national level

Table nr.5: MSMEs under the structure of gender

\begin{tabular}{|c|c|c|c|c|c|c|c|c|c|c|c|c|}
\hline 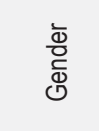 & 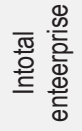 & 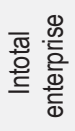 & 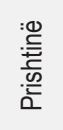 & ○ீ & 䓫 & 。 & $\begin{array}{l}: \frac{\omega}{\mathcal{Q}} \\
\bar{\alpha}\end{array}$ & 。 & 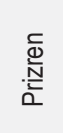 & $0^{\circ}$ & 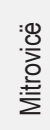 & ๙0 \\
\hline Female & 54 & 6.9 & 20 & 7.81 & 5 & 2.87 & 11 & 7.97 & 12 & 8.63 & 9 & 7.9 \\
\hline Male & 729 & 93.1 & 236 & 92.19 & 169 & 97.13 & 127 & 92.03 & 127 & 91.37 & 70 & 92.1 \\
\hline Total & 783 & 100 & 256 & 100 & 174 & 100 & 138 & 100 & 139 & 100 & 76 & 100 \\
\hline
\end{tabular}

Source: Report - Survey 800 of SMSs

The table shows that the increased participation of women in business establishment is in the Prizren region with $8.63 \%$, $7.97 \%$ region of Pec, Mitrovica region of $7.90 \%$, then $7.81 \%$ Pristina region and with little participation of women in the establishment of business is Cjilan $2.87 \%$ \%

While most large participation of men in business establishment is in Gjilan region with $97.13 \%, 92.19 \%$ Pristina region, the Mitrovica region 92.10\%, then $92.03 \%$ Pec region and in the Prizren region with 91.37\%. (mti-ks.org- Agjencia për mbështetjen e NVM-ve, 2011)

\subsection{Enterprises by fiscal number}

Of all the businesses surveyed is generally observed that MSMEs are equipped with alphanumerical fiscal fulfilling their obligations ATK calls for fiscal device number and respecting deadlines.

Table nr.6: Count MSME equipped with a fiscal number

\begin{tabular}{|c|c|c|}
\hline Equipping the fiscal numbers & Total enterprise & $\%$ \\
\hline Yes & 739 & 94.4 \\
\hline No & 44 & 5.6 \\
\hline Total & 783 & 100 \\
\hline
\end{tabular}

Source: Report - Survey 800 of SMSs

From the table we see that by 739 or $94.4 \%$ of enterprises only 44 or $5.6 \%$ of them have declared that they are not equipped with the fiscal numbers. (mti-ks.org- Agjencia për mbështetjen e NVM-ve, 2011) 


\subsection{Enterprises by spatial extent (urban \& rural)}

Spatial distribution of enterprises indicates that the enterprises except in urban areas except in rural ones. According to research conducted can conclude that $61.4 \%$ of enterprises in urban areas stretching and stretching $38.6 \%$ of them in rural areas. From this we can conclude that the extension conforms enterprise market and social and demographic developments.

Table nr.7: Structure of SMEs by extending open space

\begin{tabular}{|l|c|c|c|c|c|c|c|c|}
\hline Location & Total enterprise & $\%$ & Productive & $\%$ & Commercial & $\%$ & Service & $\%$ \\
\hline Urban & 481 & 61.4 & 123 & 51.5 & 293 & 65.8 & 65 & 65.7 \\
\hline Rural & 302 & 38.6 & 116 & 48.5 & 152 & 34.2 & 34 & 34.3 \\
\hline \multicolumn{1}{|c|}{ Total } & 783 & 100 & 239 & 100 & 445 & 100 & 99 & 100 \\
\hline
\end{tabular}

Source: Report - Survey 800 of SMSs

Can see that manufacturing activities are concentrated are already close spatial alignment SIPA same in urban and rural areas, $51.5 \%$ in urban areas and $48.5 \%$ in rural areas .. Unlike these enterprises with business activities $65.8 \%$ urban and $35.2 \%$ rural, and service enterprises dominate with $65.7 \%$ urban and $34.3 \%$ rural . (mti-ks.org Agjencia për mbështetjen e NVM-ve, 2011).

\section{Results}

* Enterprise management is important element in determining responsibility for enterprise development. From surveys conducted shows that in $86.46 \%$ of cases the owner manages the enterprise, while $13.54 \%$ of the enterprises managed by managers.

* Gender structure of founders indicates that $93.1 .0 \%$ of firm owners in small and medium enterprises are male, while only $6.9 \%$ are women. Such a structure of women's participation in the establishment of businesses remains small. However it should be noted that the trend of female participation in the establishment of enterprises has positive signs tend downs, but very slow

* Derived from surveys conclude that about $94.4 \%$ of MSMEs are provided with fiscal numbers, while only $5.6 \%$ of them still have not fulfilled their administrative duties prescribed by law for providing every business entity with fiscal number.

* Within the general information for enterprise development activities, particular importance is the spatial extent of activities, namely the development of activities of enterprises in urban and rural areas. From surveys is noted that the enterprises surveyed $61.4 \%$ of their activity in urban areas and $38.6 \%$ in rural areas.

\section{Recommendations}

* Improvement and facilitation of opening and closing businesses. A convenience where ndërmarrasi is able to enter and exit the market has profound impact on business growth and vitality of the overall private sector

* Increasing numbers of women in establishing and running businesses

* Facilitating procedures for equipment with administrative documentation, professional and technical as the number of fiscal, technical and professional licenses, etc.

* Strengthening economic relations with other countries in the region that other conditions are favorable for the penetration of local products in regional markets and beyond.

\section{Bibliography}

(n.d.).

mei-ks.org. (2012). Material për diskutim në fushën e industrisë dhe NVM-ve. Prishtinë.

mti-ks.org Agjencia për mbështetjen e NVM-ve. (2011). Hulumtimi i 800 Ndërmarrjeve të vogëla dhe të Mesme. Prishtinë.

mti-ks.org- Agjencia për mbështetjen e NVM-ve. (2011). Hulumtimi i 800 Ndërmarrjeve të Vogëla dhe të Mesme. Prishtinë.

mti-ks.org- Agjencia për mbështetjen e NVM-ve. (2011). Hulumtimi i 800 Ndërmarrjeve të Vogëla dhe të Mesme. Prishtinë. 
mti-ks.org. (2005). Hulumtimi i Ndërmarrjeve të vogëla dhe të mesme. Prishtinë.

mti-ks.org. (2011). Strategjia e zhvillimit të NVM-ve në Kosovë. Prishtinë.

mti-ks.org. (2011). Strategjia e zhvillimit të NVM-ve në Kposovë. Prishtinë.

mti-ks.org. (2011). Strategjian e zhvillimit të NVM-venë Kosovë. Prishtinë.

mti-ks.org. (2011). Strategjjia për zhvillimin e NVM-ve 2012-2016. Prishtinë.

mti-ks.org-Agjencia për mbështetjen e NVM-ve. (2011). Hulumtimi i 800 Ndërmarrjeve të Vogëla dhe të Mesme. Prishtinë.

(n.d.).

mei-ks.org. (2012). Material për diskutim në fushën e industrisë dhe NVM-ve. Prishtinë.

mti-ks.org Agjencia për mbështetjen e NVM-ve. (2011). Hulumtimi i 800 Ndërmarrjeve të vogëla dhe të Mesme. Prishtinë.

mti-ks.org- Agjencia për mbështetjen e NVM-ve. (2011). Hulumtimi i 800 Ndërmarrjeve të Vogëla dhe të Mesme. Prishtinë. mti-ks.org- Agjencia për mbështetjen e NVM-ve. (2011). Hulumtimi i 800 Ndërmarrjeve të Vogëla dhe të Mesme. Prishtinë. mti-ks.org. (2005). Hulumtimi i Ndërmarrjeve të vogëla dhe të mesme. Prishtinë.

mti-ks.org. (2011). Strategjia e zhvillimit të NVM-ve në Kosovë. Prishtinë.

mti-ks.org. (2011). Strategjia e zhvillimit të NVM-ve në Kposovë. Prishtinë.

mti-ks.org. (2011). Strategjian e zhvillimit të NVM-venë Kosovë. Prishtinë.

mti-ks.org. (2011). Strategjjia për zhvillimin e NVM-ve 2012-2016. Prishtinë.

mti-ks.org-Agjencia për mbështetjen e NVM-ve. (2011). Hulumtimi i 800 Ndërmarrjeve të Vogëla dhe të Mesme. Prishtinë.

Mustafa M, Kutllovci E, Gashi P, Krasniqi B. (2006). Biznesi i vogël dhe i mesëm. Prishtinë: Riinvest Institute.

Mustafa M, Kutllovci E, Gashi P,Krasniqi B. (2006). Biznesi i vogël dhe i mesëm. Prishtinë: Riinvest Institute.

Myftari, D. (2010). Ekonomika e ndërmarrjes. Prishtinë.

Stienholf, D. (1998). Small business managment. New York. 